\title{
MOBILITY OF SEDIMENTS DUE TO WAVE ACTION ON THE CONTINENTAL SHELF OF THE NORTHERN COAST OF THE STATE OF BAHIA
}

\author{
Raissa Helena Simões Campos $^{l}$ and José Maria Landim Dominguez $z^{2}$ \\ ${ }^{1}$ Universidade Federal da Bahia - Instituto de Geociências \\ (Rua Barão de Geremoabo, s/nº , 40.170-020 Campus Universitário de Ondina, Salvador, BA, Brasil) \\ Conselho Nacional de Desenvolvimento Científico e Tecnológico - CNPq \\ raissacampos@gmail.com \\ ${ }^{2}$ Universidade Federal da Bahia - Instituto de Geociências \\ (Rua Barão de Geremoabo, s/nº , 40170-020 Campus Universitário de Ondina, Salvador, BA, Brasil) \\ LEC/CPGG \\ landim@ufba.br
}

\begin{abstract}
A B S TR ACT
The mobility of surface sediments on the continental shelf has been investigated in this study by the use of a simple model which relates significant wave height and period $\left(\mathrm{H}_{\text {sig }}\right.$ and $\left.\mathrm{T}_{\text {sig }}\right)$ along with median sediment grain size (D50). For the $\mathrm{H}_{\text {sig }}$ and $\mathrm{T}_{\text {sig values used, sediment mobilization occurs to }}$ a maximum depth of approximately $60 \mathrm{~m}$ and encompasses virtually the entire continental shelf area. By contrast, average winter wave values of $\mathrm{H}$ and $\mathrm{T}$ can only remobilize half of this area. The seafloor area remobilized by significant wave heights and periods is in close agreement with the spatial distribution of coarse grained ripples (CGR) bedforms mapped with sidescan sonar.
\end{abstract}

\section{R E S UMO}

\begin{abstract}
A mobilidade dos sedimentos de superfície na plataforma continental nordeste do estado da Bahia foi investigada através da utilização de um modelo simples que relaciona os dados de altura e período significativos $\left(\mathrm{H}_{\text {sig }}\right.$ e $\left.\mathrm{T}_{\text {sig }}\right)$ e D50. Para os valores de $\mathrm{H}_{\text {sig }}$ e $\mathrm{T}_{\text {sig }}$ utilizados, a remobilização do sedimento ocorre até uma profundidade máxima em torno de $60 \mathrm{~m}$, em praticamente toda a área da plataforma continental. Por outro lado, valores de $\mathrm{H}$ e T médios, a remobilização ocorre em cerca de metade dessa área. A área remobilizada por ondas com altura e período significantes é compatível com ocorrência de marcas de onda de granulação grossa mapeadas por sonar de varredura lateral.
\end{abstract}

Descriptors: Northern coast of Bahia, Sediment mobility, Continental shelf.

Descritores: Litoral norte da Bahia, Mobilidade de sedimento, Plataforma continental.

\section{INTRODUCTION}

Knowledge regarding the flow conditions near the sea floor is important, for instance, to predict sediment transport and the stability of engineering structures, such as oil pipelines, and the monitoring of benthic habitat distribution. Determination of sediment mobility on continental shelves provides a basis for the characterization (?) of the spatial and temporal nature of benthic habitats, since they can be distinguished by sediment composition and grain size properties, together with transport and resuspension of detritus during storms (PORTER-SMITH et al., 2004).

On the other hand, the morphology of the sea floor contributes to the dissipation of gravitational waves, playing an important role in physical models designed to predict coastal and oceanic circulation (HOLMEDAL et al., 2003).
There are several detailed models of remobilization and transportation of sediments on continental shelves. However, due to the high computing time needed, these models have usually been applied to small spatial-temporal resolutions for which the data is sufficiently detailed (GRIFFIN et al., 2008). Less complex models, usually based on the simplification of the physical processes involved, have been used to analyze the mobility of sediments on various scales. Examples of such applications have been reported by different authors, including Harris and Coleman (1998); Porter-Smith et al. (2004) and Griffin et al. (2008). Those authors have based their studies on the simplified empirical relationships published by Clifton and Dingler (1984), in order to calculate the threshold for the mobility of sediments due to wave action. 
Global wave models can be used quantitatively to estimate the area of the continental shelf affected by waves (HARRIS; COLEMAN, 1998). The waves generated offshore by the winds determine the wave-energy arriving and dissipating in the coastal zone, forcing the coastal dynamics. Because these waves are variable in time and space, some approximation to the wave parameters for the analysis of the sediment mobility on the continental shelf on a regional scale is necessary (GRIFFIN et al, 2008). In this study we have used as wave parameters:

(1) Significant wave height $\left(\mathrm{H}_{\text {sig }}\right)$ - the average height of the largest third of waves within a certain period sampled;

(2) Significant wave period $\left(\mathrm{T}_{\text {sig }}\right)$ - the average period for waves used to define $\mathrm{H}_{\text {sig. }}$.

(3) Also, in order to undertake a more thorough analysis, average winter wave height and period $\left(\mathrm{H}_{\text {avg }}\right.$ and $\left.\mathrm{T}_{\text {avg }}\right)$ were also used.

On the other hand, sediment mobility predictions need to be checked by verification in the field. Interaction of oscillatory flows with unconsolidated sediments covering the sea floor may originate different bedform types. A type of bedform promptly recognized in sidescan records is the Coarse Grained Ripples (CGR). According to Leckie (1988), the CGR are bedforms commonly associated with the coarse sand and gravel occurring on modern continental shelves influenced by waves. The distribution of such bedforms on the continental shelf may be used as an

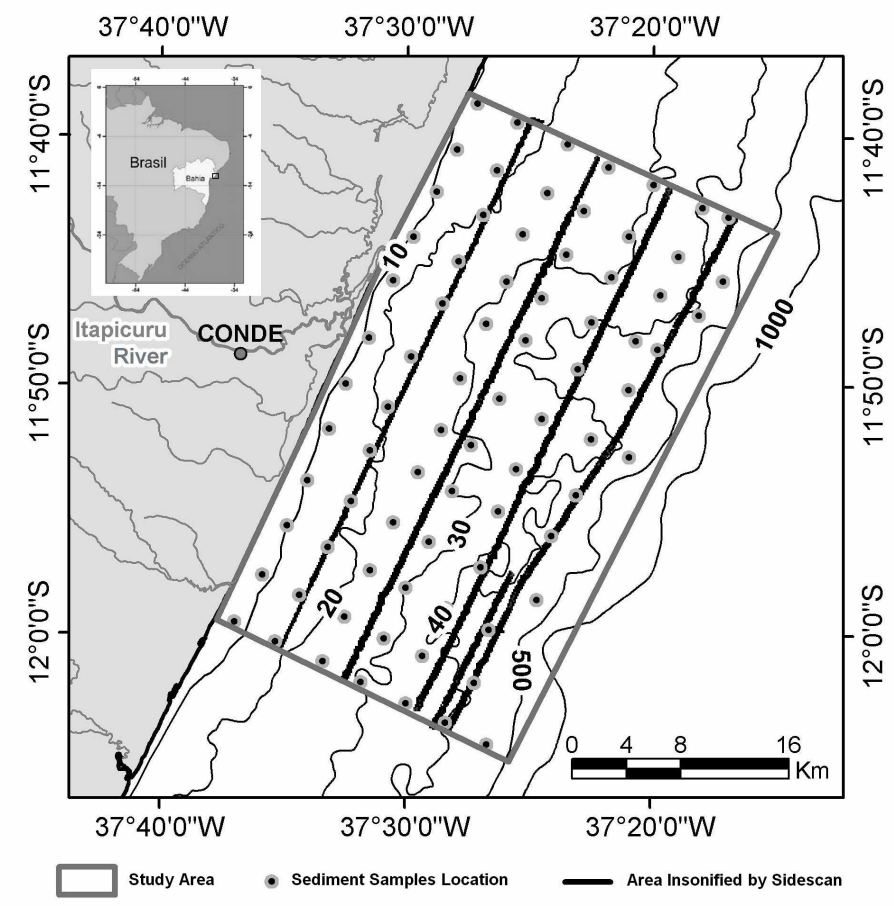

indicator of the remobilization of surface sediment by wave action. Based on these considerations, this study has as its principal objective an analysis of the mobility of the sediments on the continental shelf bordering on the municipality of Conde on the northern coast of Bahia.

\section{Study Area}

The study area (Fig. 1) is located in front of the coastal plain of the Itapicuru River, in the municipality of Conde, on the northern coast of Bahia, and encompasses an area of approximately $807 \mathrm{~km}^{2}$. The shelf edge is located at a depth of approximately $50 \mathrm{~m}$. The Itapicuru River is the main source of sediments for the region. Its drainage basin encompasses an area equivalent to $36,440 \mathrm{~km}^{2}$, with an average discharge flow of $30 \mathrm{~m}^{3} / \mathrm{second}$ (SEI, 1995). According to Silva (2008), bioclastic sediments predominate on this continental shelf. Coralline algae are the dominant bioclasts, followed by the foraminifera. Coralline algae are red algae that precipitate calcium carbonate in their cellular walls, in the form of calcite crystals (DIAS, 2000). In the study area these bioclasts are mainly associated with a sandy gravel (Ca) facies described by Silva (2008) (Fig. 2). Coralline algae clasts comprise over $90 \%$ of the sandy gravel facies. The siliciclastic fraction of the sediment is composed mainly of quartz sand (SILVA, 2000).

Fig. 1. Study area, including the distribution of the surface sediment samples used for definition of sedimentary facies, as well as for determination of the $\mathrm{D}_{50}$ values used in this study. 


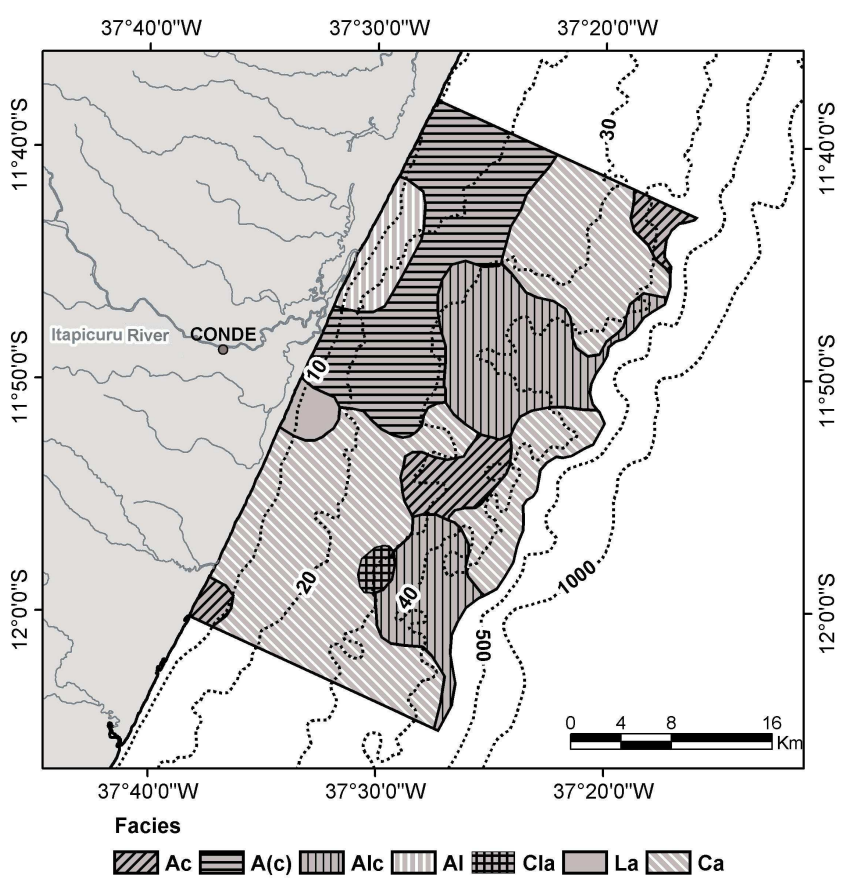

Fig. 2. Map of textural sedimentary facies covering the continental shelf bordering on the municipality of Conde, based on Folk's (1974) scheme. Facies $\mathrm{A}(\mathrm{c})=$ sand with subordinated gravel; Facies $\mathrm{Ac}=$ gravelish sand; Facies $\mathrm{Alc}=$ muddy sand with gravel; Facies $\mathrm{Al}=$ muddy sand; Facies $\mathrm{Cla}=$ sandy-muddy gravel; Facies $\mathrm{Ca}=$ sandy gravel; Facies $\mathrm{La}=$ sandy mud (modified from Silva, 2008).

According to Pianca et al. (2010), for the period from January1997 to December 2007, E/SE waves generated by trade winds were dominant in the study area. The region is also affected by cold fronts during fall/winter, when southerly waves are noticeably present. The highest waves with the longer periods are those from the SE, which are dominant in the winter time. During the summer, average wave heights ranging from 1-2 $\mathrm{m}$ with periods of between 6 and $8 \mathrm{~s}$ are typical of the easterly waves. During winter, average wave heights of $2-3 \mathrm{~m}$ and periods of $8-10$ s are dominant for southeasterly waves. The highest waves observed for the period from January 1997 - December 1997 were southeasterly, reaching a height of $4.3 \mathrm{~m}$ and a period of $17 \mathrm{~s}$.

\section{Material and Method}

Dataset

The wave parameters $\mathrm{H}_{\text {sig }}$ and $\mathrm{T}_{\text {sig }}$ for the study area, derived from frequency tables available at the Oceanographic Institute of the University of São Paulo's (IO/USP) Coastal Dynamics Lab. website $<$ http://ldc.io.usp.br/waves >, represent the 3-hourly data available from the NOAA/NCEP wave generation model WAVEWATCH III for the period extending from January 1997 to December 2007. Values of $\mathrm{H}_{\mathrm{avg}}$ and $\mathrm{T}_{\text {avg }}$ were obtained from the analysis of Pianca et al. (2010).

The bathymetric, grain size and sidescan data used in this study had been collected previously under the "Valleys Project - origin and evolution of incised valleys in the continental shelf of the state of Bahia - Case Studies: Rio Itapicuru and Lagoa Encantada", during 2006 and 2007. A total of 78 surface sediment samples were collected using a Van Veen grab sampler. Samples were spaced approximately $4 \mathrm{~km}$ one from the other. Bathymetry was assessed using an eco-sound model GPU-1650 (FURUNO) and the sidescan survey was conducted using a sidescan sonar (model Edge Tech 272-TD), operating on a frequency of $100 \mathrm{kHz}$ (Fig. 1).

\section{Wave Transformation}

For the elaboration of the wave transformation diagrams, numerical wave modeling was conducted using MIKE21® NSW, developed by DHI Water \& Environment. Mike 21 NSW is a windwave, stationary, directionally decoupled parametric 
model, based on the approach proposed by Holthuijsen et al. (1989). The model describes the propagation, growth and decay of short-period and short-crested waves in near-shore areas, taking into account the effects of refraction and shoaling due to varying depth, local wind generation and energy dissipation due to bottom friction and wave breaking. MIKE 21 NSW can be applied to the study of wave disturbance in coastal areas and to calculate the wave conditions and associated radiation stresses (for further information consult:

http://www.dhisoftware.com/upload/dhisoftwarearchiv e/papersanddocs/waves/M21_NSW >Validation.pdf )

These refracted wave height diagrams were prepared on MIKE $21 \mathrm{NSW}$ using the following wave parameters: $\mathrm{H}_{\text {sig }}(3 \mathrm{~m})$ and $\mathrm{T}_{\text {sig }}(13 \mathrm{~s}) ; \mathrm{H}_{\text {avg }}(2.5 \mathrm{~m})$ and $\mathrm{T}_{\text {avg }}(9 \mathrm{~s})$, all of them with an initial $N 135^{\circ}$ incoming direction.

The choice of the southeasterly wave direction was due to the fact that this is the dominant wave direction in winter, the most energetic season. Bathymetry was bilinearly interpolated on the MIKE® ZERO Bathymetry Editor.

Diagrams for the refracted wave height and wave period for the study area, as well as bathymetry data, were exported to ArcMap8.3 $3^{\circledR}$ software, in grid format $(100 \times 100 \mathrm{~m})$, and were subsequently converted into "Raster" type files. The median grain size (D50) of the sediment samples was converted from the phi scale into centimeters and interpolated by the IDW method $(100 \times 100 \mathrm{~m})$ in order to obtain a continuous surface.

Determination of Maximum Orbital Velocity and Critical Orbital Velocity for Onset of Movement

While it propagates on the sea surface, every wave sets the water particles in motion. When the water depth(h) is significantly greater than the wavelength of the wave (L), the wave assumes a senoidal form and the water-particle movement induced is practically circular. The orbital diameter $\left(\mathrm{d}_{\mathrm{o}}\right)$ (CLIFTON; DINGLER, 1984) is exponentially reduced as a function of depth, reaching zero at the depth corresponding to half the wavelength. In shallower water, where interaction with the sea floor takes place, the orbits described by the water particles are deformed, forming ellipses that become progressively flattened as the sea floor approaches. Immediately above the floor, the elliptical movement is transformed into a horizontal oscillation.

Based on Airy's wave theory, Komar and Miller (1998), the maximum orbital velocity at h-depth using equation 1 (Umax - maximum velocity at a fixed point on the bed) and the L-wavelength were estimated, taking the $\mathrm{H}$-wave height and the $\mathrm{T}$-wave period of the wave into consideration.

$\operatorname{Umax}=\pi \mathrm{d}_{0} / \mathrm{T}=\pi \mathrm{H} /[\mathrm{T} \sinh (2 \pi \mathrm{h} / \mathrm{L})]$

The following equations derived from Airy's wave theory were used for the calculation of the wave length $(\mathrm{L})$.

$\mathrm{L}_{\infty}=\mathrm{gT}^{2} / 2 \pi$

(Eq.2a);

$\mathrm{L}_{\mathrm{i}}=\mathrm{L}_{\infty}\left[\tanh \left(2 \pi \mathrm{h} / \mathrm{L}_{\infty}\right)\right]^{1 / 2}$

where $\mathrm{L}_{\infty}$ represents the simplification for deep water, $\mathrm{h}>\mathrm{L}_{\infty} / 2$ and $\mathrm{L}_{\mathrm{i}}$ corresponds to the general expression for intermediate water when $1 / 2>h / L_{\infty}>1 / 20$. The acceleration due to gravity is represented by $\mathrm{g}$, considered in this study to be $980 \mathrm{~cm} / \mathrm{s}^{2}$. When the near bed currents accelerate from 0 to a maximum Umax value, they may exceed the threshold value (Ucr) for the mobility of sediment, and sediment remobilization occurs.

Calculations of the critical orbital velocity for the mobility of sediment (Ucr) were carried out using the relations published by Clifton and Dingler (1984), which, for quartz density particles, expressed in $\mathrm{cm} / \mathrm{s}$ units, are reduced to:

$\mathrm{Ucr}=33.3(\mathrm{TD})^{1 / 3} \mathrm{~cm} / \mathrm{s}, \mathrm{D}_{50}<0.05 \mathrm{~cm}$

$\mathrm{Ucr}=71.4\left(\mathrm{TD}^{3}\right)^{1 / 7} \mathrm{~cm} / \mathrm{s}, \mathrm{D}_{50}>0.05 \mathrm{~cm}$

Despite the fact that the viscosity of water varies as a function of temperature and salinity, such data have been maintained constant in the equations $3 \mathrm{a}$ and 3b (CLIFTON; DINGLER, 1984). In addition to that, the density of quartz $\left(2.65 \mathrm{~g} / \mathrm{cm}^{3}\right)$ was generalized to all the sediments' constituents, since the density of calcite $\left(2.71 \mathrm{~g} / \mathrm{cm}^{3}\right)$, constituent of the cellular wall of the coralline algae which predominate in the sediments of the region, is very similar to that of quartz.

Matrix files in raster format were generated and manipulated for the different variables, using map algebra functions of ArcGis ${ }^{\circledR}$, in order to obtain the values of Umax and Ucr. The values calculated for the maximum orbital velocity (Umax) were then compared to the values calculated for the critical velocity required for the onset of sediment movement (Ucr), considering that in locations where Umax > Ucr, the sediment was mobile.

The results obtained were then compared with the spatial distribution of the CGR bedforms as interpreted (exemplified in Figure 3) in the sidescan records available for the study area. 


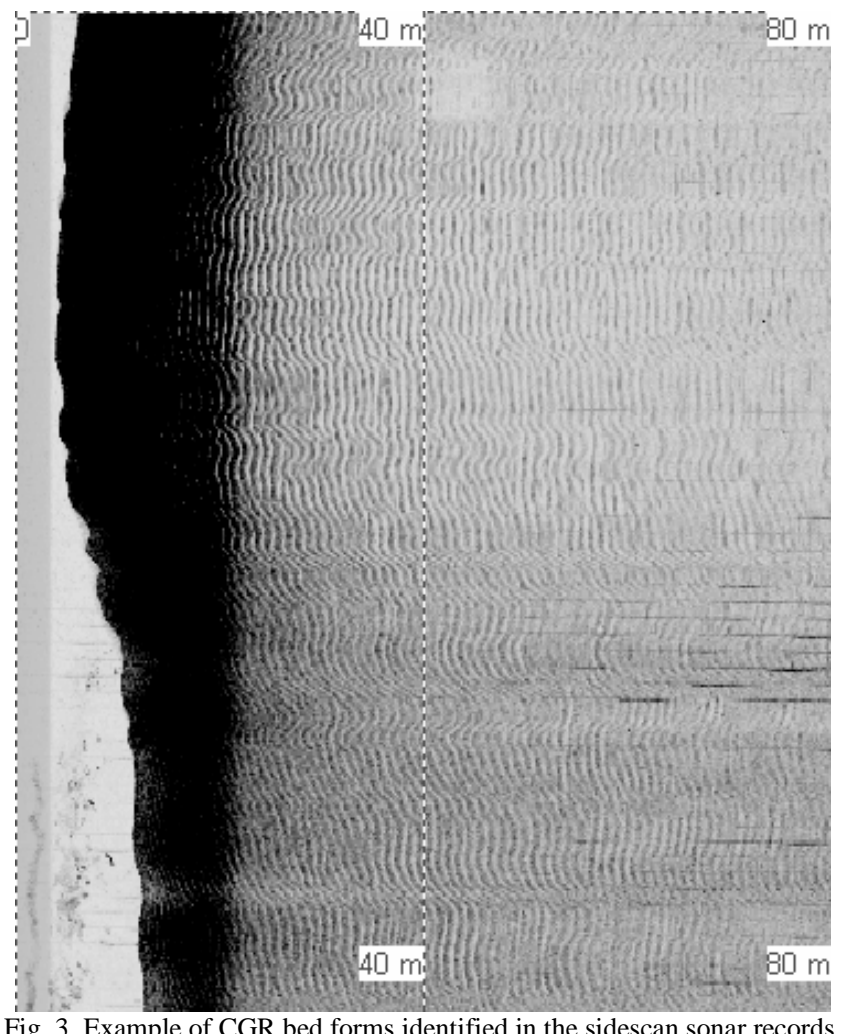

Fig. 3. Example of CGR bed forms identified in the sidescan sonar records.

\section{RESUlts}

The wave height diagrams for incoming significant waves (Fig. 4) show that the greatest heights along the shoreline occur in the southwest portion of the study area, as a result of wave focusing (convergence of wave rays). The lowest wave heights $(2-2.5 \mathrm{~m})$ occur in the center of the study area.

Regarding the values of $\mathrm{H}_{\text {sig }}$ and $\mathrm{T}_{\text {sig }}$ used in the modeling, remobilization of sediments takes place up to a maximum depth of approximately $60 \mathrm{~m}$ (Fig. 5). These results show that sediment remobilization occurs virtually throughout the continental shelf ( $95 \%)$. Modeling of sediment mobility using winter $\mathrm{H}_{\text {avg }}$ and $\mathrm{T}_{\text {avg }}$, shows that sediments are remobilized to a maximum depth of $45 \mathrm{~m}$ (Fig. 5).

The CGR bedforms identified in the sidescan sonar records are ubiquitous on all the coarse sediment facies in the study area, even at depths of $50 \mathrm{~m}$ (Fig. 5). Their distribution corroborates the modeling's results.

\section{DISCUSSION}

The lower wave heights $(2-2.5 \mathrm{~m})$ present in the center of the study area in front of the Itapicuru River mouth are probably due to the presence of the incised valley of the Itapicuru river on the shelf, causing divergence of the wave rays and therefore dissipation of wave energy. The lower wave energy in this area possibly favors the accumulation of finer grained sediments that characterizes this zone.

Areas where no remobilization of sediments took place are located offshore (Fig. 5), at depths of over $45-60 \mathrm{~m}$, and in a small portion of the middle continental shelf, where coarser grained sediments are present, together with the occurrence of lower wave heights.

The modeling using $\mathrm{H}_{\text {avg }}$ and $\mathrm{T}_{\text {avg }}$ values shows an area that is constantly being remobilized under average winter weather conditions (Fig. 5 Area Remobilized Under Average Winter Wave Conditions). The deeper remobilizations caused by average incoming winter waves occur where fine grained sediments are present, and only a small zone of coarser sediments, located in the southwest of the study area, is remobilized. The area remobilized under average winter wave conditions comprises a region approximately half the size of that remobilized by significant waves. While the former, in some places, did not even remobilize sediments at depths of less than $20 \mathrm{~m}$, the latter remobilized the sediment throughout the shelf and even beyond it. 


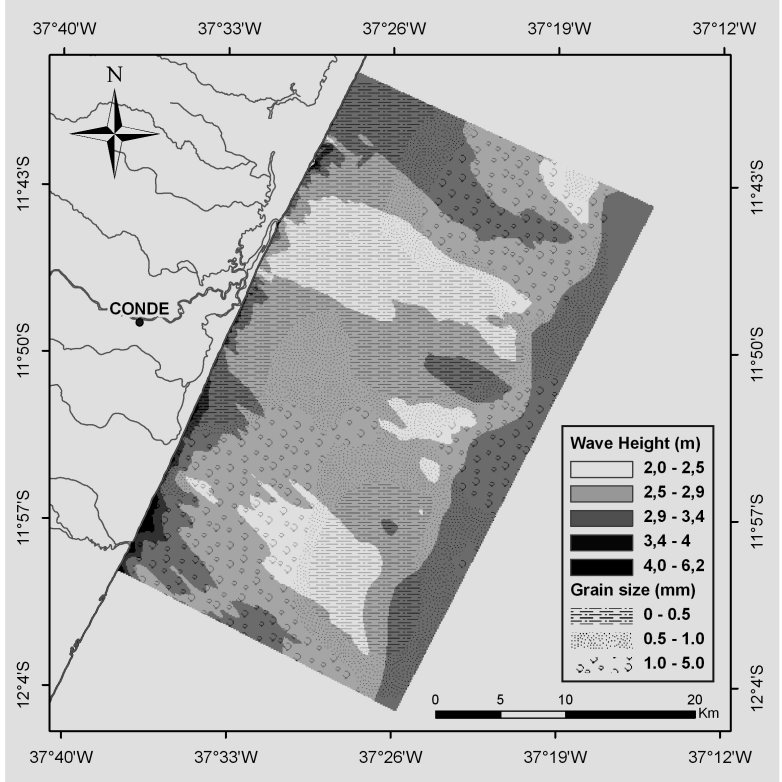

Fig. 4. Wave height diagram of incoming significant waves and grain size distribution.

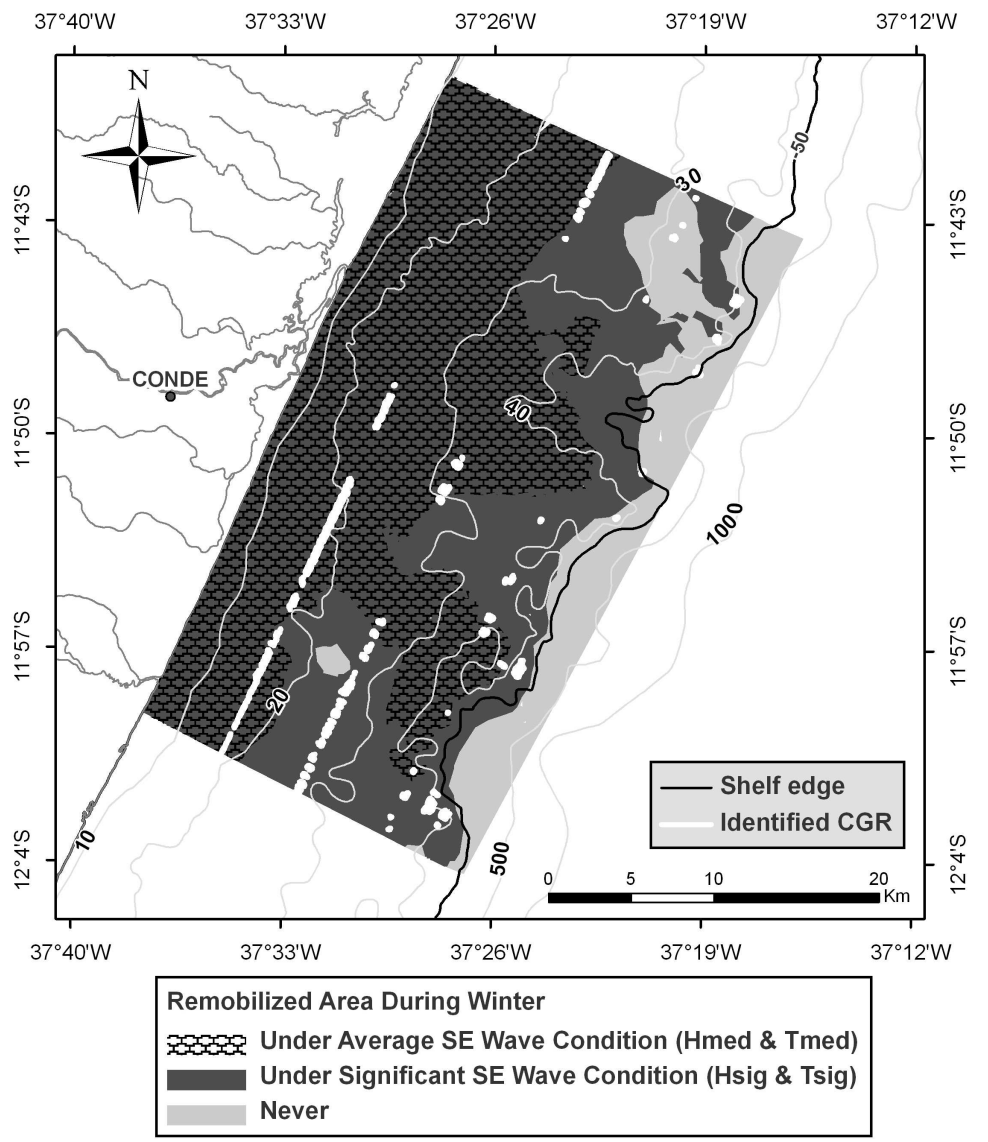

Fig. 5. Area remobilized during winter and identified CGR-type bedform. 
The comparison of the modeling results with the spatial distribution of CGR bedforms shows a close agreement with the sediment mobility diagram when using the significant wave height and period (Fig. 5). Indeed, the $\mathrm{H}_{\text {sig }}$ and $\mathrm{T}_{\text {sig }}$ values for the area are very close to those for $\mathrm{H}$ and $\mathrm{T}$ indicated by LaPierre and Boyd [(1985), apud Leckie, 1987)] as the optimal conditions for formation of Coarse Grained Ripples, at depths up to $40 \mathrm{~m}$ : waves with periods ranging from 10 to 12 seconds and heights of from 3 to $5 \mathrm{~m}$. Further, most of the CGR identified in the study area were located at depths that were not susceptible to remobilization by average winter waves, indicating that these CGR bedforms must have been generated exclusively by significant values. As the total number of yearly occurrences of significant events (wave heights above $3 \mathrm{~m}$ ) is 4.09 (PIANCA et al., 2010), the CGR on most of the continental shelf area are probably generated during very infrequent events, such as storms and the passage of cold fronts, when $\mathrm{H}$ is relatively larger and $\mathrm{T}$ can be much longer.

\section{Conclusions}

This study demonstrated that it is possible to analyze the mobility of sediments on the continental shelf bordering on the municipality of Conde by comparing the maximum orbital velocity and the critical orbital velocity for remobilization of the sea floor.

The CGR-type bedform distribution in sidescan sonar records were compared to diagrams of sediment remobilization due to wave action. About $95 \%$ of the seafloor in the shelf area is remobilized by significant wave heights and periods, a finding corroborated by CGR bedform distribution. Average winter waves were capable of remobilizing sediments in only half of the shelf area. This suggests that the sediment of the entire shelf of the study area can be remobilized during episodic events such as storms or the passage of intense cold fronts.

\section{ACKNOWLEDGMENTS}

R.H.S.Campos wishes to express her thanks to the CNPq for the scientific initiation scholarship granted for the execution of this project. J.M.L. Dominguez holds a CNPq research fellowship. The authors would also like to thank an anonymous reviewer for the great suggestions and constructive comments made about this study.

\section{REFERENCES}

CLIFTON, H. E.; DINGLER, J. R. Wave-formed structures and paleoenvironmental reconstruction. Mar. Geol., v. 60, p. 165-198, 1984.

DIAS, G. T. M. Granulados Bioclásticos - Algas Calcárias. Rev. bras. Geofis., v.18, n. 3, p. 307- 318, 2001.

GRIFFIN, J. D.; HEMER, M. A.; JONES, B. G. Mobility of sediment grain size distributions on a wave dominated continental shelf, southeastern Australia. Mar. Geol., v. 252, n. 1-2, p. 13-23, 2008.

HARRIS, P. T.; COLEMAN, R. Estimating global shelf sediment mobility due to swell waves. Mar. Geol., v. 150, p. 171-177, 1998.

HOLTHUIJSEN, L. H.; BOOJI, N.; HERBERS, T. H. S. A prediction model for stationary, short-crested waves in shallow water with ambient currents. Coastal Eng. Journal, V. 13, 23-54, 1989.

HOMEDAL, L. E.; MYRHAUG, D.; RUE, H. The sea bed boundary layer under random waves plus current. Cont. Shelf Res., v. 23, n. 7, p. 717-750, 2003.

KOMAR, P. D. Beach Processes and Sedimentation. 2nd ed. Upper Saddle River, NJ.: Prentice Hall, 1998. 544 p.

KOMAR, P. D.; MILLER, M. C. The threshold of sediment movement under oscillatory water waves. J. sediment. Petrol., v. 43, p. 1101-1110, 1973.

LAPIERRE, A.; BOYD, R. Coarse-grained megaripples on Eastern Shore, Inner Shelf, Nova Scotia. In: FORBES, D. L. (Ed.). CANADIAN COASTAL CONFERENCE, 1985, Ottawa. Proceedings... National Research Council of Canada, Associate Committee for Research on Shoreline Sedimentation, $13-16$, p. 121-142, 1985.

LECKIE, D. Wave-formed, course-grained ripples and their relationship to hummock cross-stratification. J. sediment. Petrol., v. 58, p. 607- 622, 1988.

PIANCA, C.; MANZZINI, P. L. F.; SIEGLE, E. Brazilian offshore wave climate based on NWW3 reanalysis. Braz. J. Oceanogr.,v. 58, n. 1, p. 53-70, 2010.

PORTER-SMITH, R.; HARRIS, P. T.; ANDERSON, O. B.; COLEMAN, R.; GREENSLADE, D.; JENKINS, C. J. Classification of the Australian continental shelf base on predicted sediment threshold exceedance from tidal currents and swell waves. Mar. Geol., v. 211, p. 1-20, 2004.

SILVA, E. N. S. A sedimentação na Plataforma Continental do Município de Conde (Litoral Norte da Bahia) desde o ultimo máximo glacial: Integração de dados sedimentológicos e geofísicos. 2008. Trabalho final de graduação. Curso de Bacharel em Geologia, Universidade Federal da Bahia, 2008.

SEI - SUPERINTENDÊNCIA DE ESTUDOS ECONÔMICOS E SOCIAIS DA BAHIA. Plano Diretor de Recursos Hídricos - Baia do Itapicuru, 1995. 242 p. Documento Síntese.

(Manuscript received 03 June 2009; revised 15 December 2009; accepted 09 March 2010) 